\title{
Effectiveness of fundamental resonant frequency for determining the elastic properties of Argentinean Eucalyptus grandis in structural sizes
}

Published online: 9 December 2003

(C) Springer-Verlag 2003

\begin{abstract}
The present paper reports the results of an investigation regarding the elastic properties of Argentinean Eucalyptus grandis by the dynamic method of measuring the fundamental frequencies of vibration. It aims at scrutinising how that method is suitable to this timber species. For this purpose an empirical research project with one sample of boards and four samples of beams in structural sizes exhibiting a wide range of variation in quality was carried out. The results give evidence of the effectiveness of this method for determining the elastic properties for Argentinean Eucalyptus grandis in different sizes, and that it is reliable for pieces of high quality as well as for those containing important strength and stiffness reducing factors, such as the presence of pith, among others.
\end{abstract}

\section{Leistungsfähigkeit von Resonanzschwingungen zur Bestimmung der Elastizitätseigenschaften von Eukalyptus grandis in Bauholzabmessungen aus Argentinien}

Zusammenfassung Die Ergebnisse experimenteller Untersuchungen zur Bestimmung der Elastizitätseigenschaften von argentinischen Eukalyptus grandis Hölzern durch Schwingungsmessungen werden vorgestellt. Um die Brauchbarkeit dieser Methode für dieses Holz zu untersuchen, wurden eine Stichprobe mit Brettern und vier

\author{
J. C. Piter \\ Departamento de Ingeniería Civil, \\ Facultad Regional Concepción del Uruguay, \\ Universidad Tecnológica Nacional, \\ Ing. Pereira 676, (E3264BTD) C. del Uruguay, Entre Ríos, \\ Argentina \\ R. L. Zerbino \\ Departamento de Ingeniería Civil, Facultad de Ingeniería, \\ Universidad Nacional de La Plata, \\ 48 y 115, (1900) La Plata, Buenos Aires, Argentina \\ H. J. Blaß (๘) \\ Lehrstuhl für Ingenieurholzbau und Baukonstruktionen, \\ Universität Karlsruhe, 76128 Karlsruhe, Germany \\ e-mail: hans.blass@holz.uka.de
}

Stichproben mit Kanthölzern in Bauholzabmessungen untersucht. Die Ergebnisse zeigen die Leistungsfähigkeit dieser Methode für Prüfkörper unterschiedlicher Abmessungen und Qualitäten.

\section{Introduction}

Paper 1 of this series (Piter et al., submitted to Holz als Roh- und Werkstoff) reported on the design of a method for visually grading sawn timber of Argentinean Eucalyptus grandis. Paper 2 (Piter et al., submitted to Holz als Roh- und Werkstoff) referred to the possibility of machine strength grading the same material. The determination of the modulus of elasticity (MOE) is a topic of great importance for timber structures. It is used for calculating the deflections, the load-carrying capacity of slender members subjected to compression stress, and it is one of the most important machine strength grading parameters. As an alternative to bending, other nondestructive evaluation methods have been employed to determine the modulus of elasticity, such as vibration, ultrasound and microwaves (Glos 1995; Görlacher 1997).

The mechanical resonant frequencies of elastic materials at ambient temperatures are determined by the modulus of elasticity, mass, and geometry of the piece. As a consequence, the dynamic modulus of elasticity can be calculated for a test specimen if its fundamental frequency of vibration, geometry, dimensions and mass are determined (ASTM 1998). This method has also been utilised for investigating the elastic properties of an anisotropic building material as timber both in small clear and in structural sizes, and for coniferous as well as for deciduous species (Görlacher 1984; Ilic 2001).

The aim of this paper is to present the relationship between the static modulus of elasticity in bending and in tension parallel to the grain, and the dynamic modulus of elasticity calculated by both longitudinal and bending vibrations, for test samples with varied quality and usual structural sizes of Eucalyptus grandis cultivated in the Mesopotamian Provinces of Argentina. Through the 
discussion and comparison of these relationships with other investigations, the potential and effectiveness of the dynamic method for calculating the elastic properties of this timber species is determined.

\section{Materials and methods}

Materials, static tests and methods for determining moisture content and density were described in paper 1 . In the present investigation the same data corresponding to 200 beams (samples 1 to 4) and 142 boards of Sample 6 were used.

Fundamental resonant frequency of the test specimens was determined by exciting them mechanically by an impact in the direction of the vibration. With the aim to allow a free vibration without extraneous interference, supports of polyurethane foam strips were located centrally for analysing longitudinal vibrations, and in the nodal positions $(0.224 l$ from each end) for determining the first flexural mode of vibration. Longitudinal frequency was analysed by lightly impacting an end cross section with a small tool, and recording the resulting mechanical vibrations by contacting the other end cross section with a direct contact transducer. Fundamental flexural frequency was determined by lightly striking at one end, and placing the direct contact transducer at the centre of the specimen (anti-node point). For boards this type of analysis was made flatwise, for Sample 1 edgewise, and for samples 2, 3 and 4 both flatwise and edgewise. The detection system consisted of a piezoelectric accelerometer type Vibrator PZ-10. This tracer transformed the vibrations into electric signals. The signal analysis system consisted of an oscilloscope Fluke 123 Scopemeter $20 \mathrm{MHz}$, an interface and a computer with the Fluke View software. This software presented the harmonic spectrum and allowed to identify the fundamental frequency of vibration through a fast Fourier transformation. The test was repeated several times and the average of the five most similar readings were used in the calculations.

Both the dynamic longitudinal and flexural modulus of elasticity were calculated from the standard solution (Goens 1931; Kollman \& Krech 1960; Hearmon 1966):

$E_{l}=\frac{4 l^{2} f_{l}^{2} \rho}{n^{2}}$

$E_{f}=\frac{4 \pi^{2} l^{4} f_{f}^{2} \rho}{m_{n}^{4} i^{2}}\left(1+\frac{i^{2}}{l^{2}} k_{1}\right)$

where $E_{l}=$ dynamic longitudinal modulus of elasticity, $l=$ specimen length, $f_{1}=$ fundamental longitudinal frequency, $\rho$ = bulk density, $\quad n=$ mode of vibration $(n=1,2,3), E_{f}=$ dynamic flexural modulus of elasticity, $f_{f}=$ fundamental flexural frequency, $m_{n}{ }^{4}$ and $k_{1}=$ constants dependent of the mode of vibration (equal to 500.6 and 49.48 respectively for the first mode), $i=$ radius of gyration in direction of the bending vibrations.
Taking into account that the span-to-depth ratio for this case was greater than $15: 1$, and that when determining the global static modulus of elasticity in bending the influence of shear is ignored, the influence of the shear modulus was also disregarded in Eq. 2 (Görlacher 1984).

\section{Results and discussion}

The main results of the investigated properties are summarised in Tables 1 and 2 . The mean value of moisture content was $14.5 \%$ for the 142 boards and $14.7 \%$ for the 200 beams. The mean value for the bulk density ( $\rho$ ) was $579 \mathrm{~kg} / \mathrm{m}^{3}$ and $551 \mathrm{~kg} / \mathrm{m}^{3}$ respectively, with low coefficient of variation $(0.10$ and 0.13$)$.

In the test series corresponding to boards, the mean dynamic longitudinal $\left(E_{l}\right)$ and flexural $\left(E_{f}\right)$ modulus of elasticity were $90 \%$ and $95 \%$ of the static value in tension parallel to the grain $\left(E_{t, 0}\right)$, respectively, with similar coefficients of variation $(0.19 / 0.20)$. In contrast to the board results, the results for beams exhibited greater values for the dynamic modulus MOE. The dynamic longitudinal modulus of elasticity was $3 \%$ greater than de global static modulus of elasticity in bending $\left(E_{m, g}\right)$, and the dynamic flexural modulus of elasticity was $2 \%$ and $4 \%$ greater, in flatwise and edgewise bending, respectively. The coefficient of variation was 0.18 for the static MOE (0.17 considering only Samples 2, 3 and 4) and it ranged from 0.19 to 0.23 for the dynamic MOE. Görlacher (1984) found a mean value for the dynamic flexural MOE about 9\% higher than the static value determined according to DIN 52186, with both clear specimens and beams in structural sizes from Douglas-fir. Ilic (2001) reported a mean value for the dynamic longitudinal modulus of elasticity $29 \%$ greater than the

Table 1 Summary of the results for 142 boards subjected to tension tests. (F) Flatwise

Tabelle 1 Zusammenfassung der Ergebnisse der Zugversuche mit 142 Brettern. (F) Flachkant

\begin{tabular}{lllll}
\hline & $\begin{array}{l}\rho \\
\left(\mathrm{kg} / \mathrm{m}^{3}\right)\end{array}$ & $\begin{array}{l}E_{t, 0} \\
\left(\mathrm{~N} / \mathrm{mm}^{2}\right)\end{array}$ & $\begin{array}{l}E_{l} \\
\left(\mathrm{~N} / \mathrm{mm}^{2}\right)\end{array}$ & $\begin{array}{l}E_{f}(\mathrm{~F}) \\
\left(\mathrm{N} / \mathrm{mm}^{2}\right)\end{array}$ \\
\hline Mean & 579 & 12800 & 11500 & 12200 \\
$\mathrm{~s}$ & 56 & 2470 & 2260 & 2300 \\
\hline
\end{tabular}

Table 2 Summary of the results for 200 beams subjected to bending tests (Samples 1 to 4). (E) Edgewise; (F) Flatwise; *Only for samples 2, 3 and 4

Tabelle 2 Zusammenfassung der Ergebnisse der Biegeversuche mit 200 Biegeprüfkörpern (Proben 1 bis 4). (E) Hochkant; (F) Flachkant; *Nur für Proben 2, 3 und 4

\begin{tabular}{llllll}
\hline & $\begin{array}{l}\rho \\
\left(\mathrm{kg} / \mathrm{m}^{3}\right)\end{array}$ & $\begin{array}{l}E_{m, g}(\mathrm{E}) \\
\left(\mathrm{N} / \mathrm{mm}^{2}\right)\end{array}$ & $\begin{array}{l}E_{l} \\
\left(\mathrm{~N} / \mathrm{mm}^{2}\right)\end{array}$ & $\begin{array}{l}E_{f}(\mathrm{~F}) \\
\left(\mathrm{N} / \mathrm{mm}^{2}\right)\end{array}$ & $\begin{array}{l}E_{f}(\mathrm{E}) \\
\left(\mathrm{N} / \mathrm{mm}^{2}\right)\end{array}$ \\
\hline Mean & 551 & $\begin{array}{l}11800 \\
\left(12200^{*}\right)\end{array}$ & 12200 & $12400^{*}$ & 12300 \\
$\mathrm{~s}$ & 73 & $\begin{array}{c}2070 \\
\left(2050^{*}\right)\end{array}$ & 2770 & $2470^{*}$ & 2350 \\
\hline
\end{tabular}


Table 3 Correlation coefficients between static modulus of elasticity in tension parallel to the grain and in bending, and the dynamic modulus of elasticity calculated by longitudinal and flexural vibrations. (F) Flatwise; (E) Edgewise; *Only for samples 2,3 and 4

Tabelle 3 Korrelationskoeffizienten zwischen den statischen Zugund Biegeelastizitäsmoduln und den dynamischen Elastizitätsmoduln ermittelt aus Longitudinal- und Biegeschwingungen. (F) Flachkant; (E) Hochkant; *Nur für Proben 2, 3 und 4

\begin{tabular}{llll}
\hline & $E_{l}$ & $E_{f}(\mathrm{~F})$ & $E_{f}(\mathrm{E})$ \\
\hline$E_{t, 0}($ (142 boards) & 0.85 & 0.92 & - \\
$E_{m, g}$ (Samples 1 to 4) & 0.86 & $0.92 *$ & 0.93 \\
$E_{m, g}$ (Sample 1) & 0.83 & - & 0.94 \\
$E_{m, g}$ (Sample 2) & 0.88 & 0.95 & 0.97 \\
$E_{m, g}$ (Sample 3) & 0.88 & 0.85 & 0.93 \\
$E_{m, g}$ (Sample 4) & 0.84 & 0.93 & 0.97 \\
\hline
\end{tabular}

corresponding static value (three point bending) for test specimens with $20 \mathrm{~mm} \times 20 \mathrm{~mm}$ cross section of Australian Eucalyptus delegatensis, and $11 \%$ greater for the dynamic flexural modulus, with greater coefficient of variation than the ones found in this study. In a test series with boards in structural sizes free of growth centre (pith) of Uruguayan Eucalyptus grandis with moisture content of 26\%, Pérez del Castillo (2001) found mean values for the longitudinal dynamic modulus of elasticity from $6 \%$ to $13 \%$ higher than the static value in bending (flatwise), determined for different spans (three point bending). In a test series with the same boards at $12 \%$ moisture content he found a mean value for the longitudinal dynamic MOE $3 \%$ higher than the static MOE.

The relationships between the static and the dynamic elastic properties for boards and beams, indicated by correlation coefficients, are summarised in Table 3. The values show that the flexural dynamic modulus of elasticity is highly related to the static both in tension and in bending, with very good correlation coefficients of 0.92 for boards and beams (flatwise) and 0.93 for beams (edgewise). The longitudinal dynamic modulus shows a lower correlation coefficient with the static than the flexural, but still exhibiting values of 0.85 and 0.86 for boards and beams respectively. Ilic (2001) reported correlation coefficients of 0.95 between longitudinal dynamic and static modulus, and 0.99 between flexural dynamic and static modulus, for three point bending tests with small specimens of Australian Eucalyptus delegatensis. A very good correlation coefficient of 0.98

Table 5 Summary of results for beams (Samples 1 to 4) without the growth centre (pith), in comparison with the ones including it. (E) Edgewise; (F) Flatwise; **Only for Samples 2, 3 and 4
Table 4 Summary of results for boards without the growth centre (pith) in comparison with the ones including it. (F) Flatwise Tabelle 4 Zusammenfassung der Ergebnisse für markfreie Bretter im Vergleich mit denjenigen mit Markröhre. (F) Flachkant

\begin{tabular}{lllccc}
\hline & & $\begin{array}{l}\rho \\
\left(\mathrm{kg} / \mathrm{m}^{3}\right)\end{array}$ & $\begin{array}{l}E_{t, 0} \\
\left(\mathrm{~N} / \mathrm{mm}^{2}\right)\end{array}$ & $\begin{array}{l}E_{l} \\
\left(\mathrm{~N} / \mathrm{mm}^{2}\right)\end{array}$ & $\begin{array}{l}E_{f}(\mathrm{~F}) \\
\left(\mathrm{N} / \mathrm{mm}^{2}\right)\end{array}$ \\
\hline $\begin{array}{l}\text { Without } \\
\text { pith } \\
(\mathrm{n}=98)\end{array}$ & Mean & 584 & 13500 & 12100 & 12900 \\
With pith & Mean & 568 & 11100 & 10100 & 10500 \\
$(\mathrm{n}=44)$ & $\mathrm{s}$ & 54 & 1710 & 1730 & 1480 \\
\hline
\end{tabular}

between the longitudinal dynamic and the static modulus of elasticity was obtained by Pérez del Castillo (2001) for boards of Uruguayan Eucalyptus grandis, free of pith, and with $26 \%$ moisture content.

In order to discuss the relationship between the dynamic and static elastic properties for test specimens with different dimensions, the correlation coefficients corresponding to beams of Samples 1 to 4 are shown separately in Table 3. The results indicate values ranging from 0.83 to 0.88 for the dynamic longitudinal MOE, from 0.85 to 0.95 for the dynamic flexural MOE, flatwise, and from 0.93 to 0.97 edgewise. In no case it was possible to find a relationship between the specimen sizes and the correlation coefficients. The value of 0.85 corresponding to sample 3 for flexural dynamic modulus, flatwise, is considerably lower than those of 0.95 and 0.93 for Samples 2 and 4. Nevertheless, an influence of the specimen size is not assumed, because the size was smaller for Sample 2 and greater for Sample 4.

The presence of timber adjacent or including the growth centre (pith) significantly reduces the strength and stiffness properties of this timber species (see paper 1). The effectiveness of the dynamic method was therefore verified for both the specimens with and without pith. The main results are shown in Table 4 for boards and in Table 5 for beams. The mean value of the dynamic longitudinal and flexural modulus were $90 \%$ and $96 \%$ of the static value for boards free of pith, and $91 \%$ and $94 \%$ for the ones with pith, with similar coefficients of variation. Examination of Table 5 for beams shows values for the dynamic longitudinal and flexural modulus of elasticity of 4\%,6\% (flatwise) and 5\% (edgewise) greater than the static value for specimens free of pith, whereas $2 \%$ greater in both the longitudinal and flexural

\begin{tabular}{|c|c|c|c|c|c|c|}
\hline & & $\begin{array}{l}\rho \\
\left(\mathrm{kg} / \mathrm{m}^{3}\right)\end{array}$ & $\begin{array}{l}E_{m, g}(\mathrm{E}) \\
\left(\mathrm{N} / \mathrm{mm}^{2}\right)\end{array}$ & $\begin{array}{l}E_{l} \\
\left(\mathrm{~N} / \mathrm{mm}^{2}\right)\end{array}$ & $\begin{array}{l}E_{f}(\mathrm{~F}) \\
\left(\mathrm{N} / \mathrm{mm}^{2}\right)\end{array}$ & $\begin{array}{l}E_{f}(\mathrm{E}) \\
\left(\mathrm{N} / \mathrm{mm}^{2}\right)\end{array}$ \\
\hline $\begin{array}{l}\text { Without pith } \\
n=110\left(74^{* *}\right)\end{array}$ & $\begin{array}{l}\text { Mean } \\
\text { S }\end{array}$ & $\begin{array}{r}570 \\
81\end{array}$ & $\begin{array}{c}12400\left(13000^{* *}\right) \\
2230(2230 * *)\end{array}$ & $\begin{array}{r}12900 \\
2970\end{array}$ & $\begin{array}{l}13700^{* *} \\
2530^{* *}\end{array}$ & $\begin{array}{r}13000 \\
2510\end{array}$ \\
\hline $\begin{array}{l}\text { With pith } \\
n=90\left(76^{* *}\right)\end{array}$ & $\begin{array}{l}\text { Mean } \\
\text { S }\end{array}$ & $\begin{array}{r}529 \\
54\end{array}$ & $\begin{array}{c}11100\left(11400^{* *}\right) \\
1590\left(1480^{* *}\right)\end{array}$ & $\begin{array}{r}11400 \\
2230\end{array}$ & $\begin{array}{r}11200^{* *} \\
1650^{* *}\end{array}$ & $\begin{array}{r}11300 \\
1730\end{array}$ \\
\hline
\end{tabular}

Tabelle 5 Zusammenfassung der Ergebnisse für markfreie Biegeprüfkörper (Proben 1 bis 4 ) im Vergleich mit denjenigen mit Markröhre. (E) Hochkant; (F) Flachkant; **Nur für Proben 2, 3 und 4 


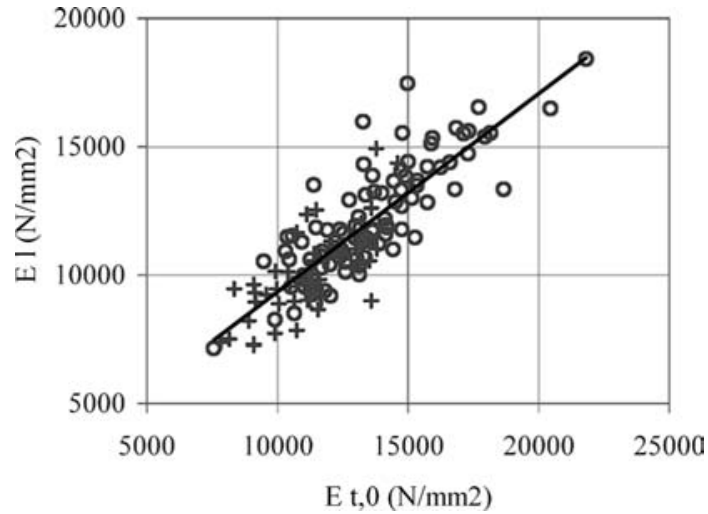

Fig. 1 Relationship between the static modulus of elasticity in tension parallel to the grain $\left(E_{t, 0}\right)$ and the dynamic longitudinal modulus of elasticity $\left(E_{l}\right)$ for 142 boards. Correlation coefficients: whole sample $=0.85$; pieces free of pith $(\mathrm{o})=0.83$; pieces containing pith $(+)=0.73$. Linear regression equation: $E_{l}=0.7724 E_{t, 0}+1617$ Abb. 1 Zusammenhang zwischen dem statischen Zug-Elastizitätsmodul $\left(E_{t, 0}\right)$ und dem dynamischen Elastizitätsmodul ermittelt aus Longitudinalschwingungen $\left(E_{l}\right)$ für 142 Bretter Korrelationskoeffizienten: Alle Prüfkörper $=0.85$; Markfreie Prüfkörper $(o)=0.83$; Prüfkörper mit Markröhre $(+)=0.73$. Lineare Regressionsgleichung: $E_{l}=0.7724 E_{t, 0}+1617$

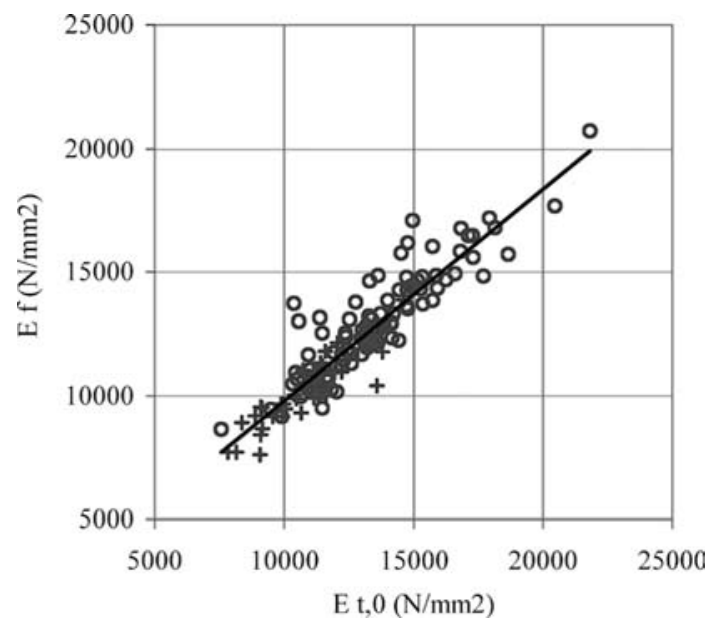

Fig. 2 Relationship between the static modulus of elasticity in tension parallel to the grain $\left(E_{t, 0}\right)$ and the dynamic flexural modulus of elasticity $\left(E_{f}\right)$ (flatwise) for 142 boards. Correlation coefficients: whole sample $=0.92$; pieces free of pith $(\mathrm{o})=0.90$; pieces containing pith $(+)=0.91$. Linear regression equation: $E_{f}=0.8558 E_{t, 0}+1235.5$ Abb. 2 Zusammenhang zwischen dem statischen Zug-Elastizitätsmodul $\left(E_{t, 0}\right)$ und dem dynamischen Elastizitätsmodul ermittelt aus Biegeschwingungen $\left(E_{f}\right)$ (Flachkant) für 142 Bretter Korrelationskoeffizienten: Alle Prüfkörper=0.92; Markfreie Prüfkörper $(\mathrm{o})=0.90$; Prüfkörper mit Markröhre $(+)=0.91$. Lineare Regressionsgleichung: $E_{f}=0.8558 E_{t, 0}+1235.5$

edgewise for the ones containing it. The mean dynamic flexural modulus, flatwise, was in this case $98 \%$ of the static value for Samples 2, 3 and 4. These relations, in comparison with those of Tables 1 and 2, demonstrate that the dynamic method is equally suitable for different qualities of timber, even for pieces containing important imperfections such as pith, among others.

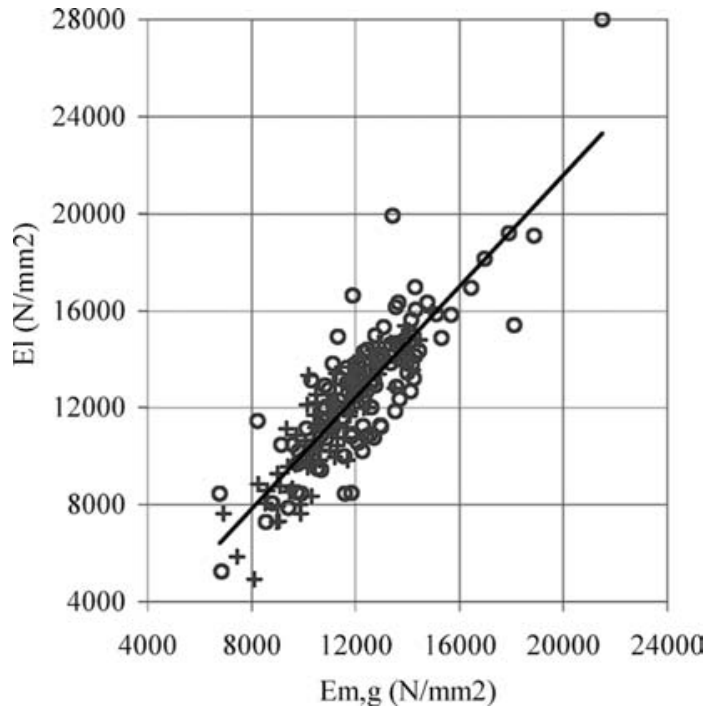

Fig. 3 Relationship between the static modulus of elasticity in bending $\left(E_{m, g}\right)$ (edgewise) and the dynamic longitudinal modulus of elasticity $\left(E_{l}\right)$ for beams of Samples 1 to 4 . Correlation coefficients: whole sample $=0.86$; pieces free of pith $(\mathrm{o})=0.83$; pieces containing pith $(+)=0.88$. Linear regression equation: $E_{l}=1.1476 E_{m, g}-1357.5$ Abb. 3 Zusammenhang zwischen dem statischen Biege-Elastizitätsmodul $\left(E_{m, g}\right)$ (Hochkant) und dem dynamischen Elastizitätsmodul ermittelt aus Longitudinalschwingungen $\left(E_{l}\right)$ für Proben 1 bis 4. Korrelationskoeffizienten: Alle Prüfkörper $=0.86$; Markfreie Prüfkörper (o) $=0.83$; Prüfkörper mit Markröhre $(+)=0.88$. Lineare Regressionsgleichung: $E_{l}=1.1476 E_{m, g}-1357.5$

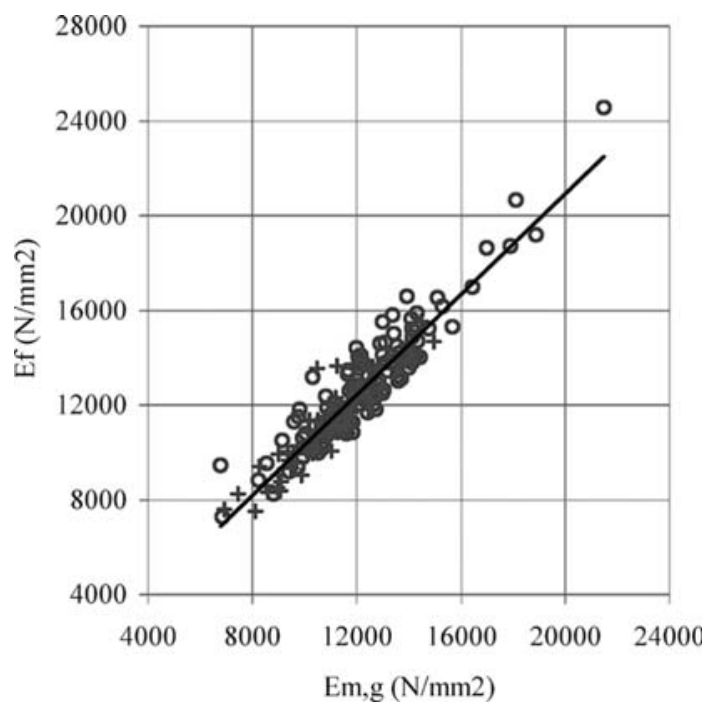

Fig. 4 Relationship between the static modulus of elasticity in bending $\left(E_{m, g}\right)$ (edgewise) and the dynamic flexural modulus of elasticity $\left(E_{f}\right)$ (edgewise) for beams of Samples 1 to 4 . Correlation coefficients: whole sample $=0.93$; pieces free of pith (o) $=0.93$; pieces containing pith $(+)=0.93$. Linear regression equation: $E_{f}=1.0595 E_{m, g}-276.56$

Abb. 4 Zusammenhang zwischen dem statischen Biege-Elastizitätsmodul $\left(E_{m, g}\right)$ (Hochkant) und dem dynamischen Elastizitätsmodul ermittelt aus Biegeschwingungen $\left(E_{f}\right)$ (Hochkant) für Proben 1 bis 4 . Korrelationskoeffizienten: Alle Prüfkörper=0.93; Markfreie Prüfkörper (o) $=0.93$; Prüfkörper mit Markröhre $(+)=0.93$. Lineare Regressionsgleichung: $E_{f}=1.0595 E_{m, g}-276.56$ 
In Figs. 1 and 2 the relationships between the static modulus of elasticity in tension parallel to the grain and the dynamic longitudinal and flexural (flatwise), respectively, for boards are shown. The correlation coefficients for the whole sample were 0.85 and 0.92 , respectively, as indicated in Table 3. The specimens free of pith presented correlation coefficients of 0.83 in the first case and of 0.90 in the second one, whereas the pieces with pith presented values of 0.73 and 0.91 .

Figures 3 and 4 show the relationships between the static global modulus of elasticity in bending and the dynamic longitudinal and flexural (edgewise) MOE, respectively, for beams of Samples 1 to 4 . The correlation coefficients were 0.86 and 0.93 as indicated in Table 3 for the whole samples. The pieces free of pith show values of 0.83 and 0.93 for the different dynamic methods, and those containing the growth centre presented correlation coefficients of 0.88 and 0.93 . In the four figures it is obvious that the specimens free of pith exhibited generally greater values for both static and dynamic elastic properties but similar correlation coefficients. The single exception was the smallest value of 0.73 for the correlation coefficient between the longitudinal dynamic modulus and the corresponding static value in tension parallel to the grain for boards with pith. This decrease only appeared for this case, whereas the value for the same pieces resulted in a correlation coefficient of 0.91 between the dynamic flexural modulus and the static in tension.

\section{Conclusions}

It was possible to determine the elastic modulus of elasticity for boards and beams in structural sizes of Argentinean Eucalyptus grandis by means of impulse excitation of vibration. The specimens of different sizes exhibited a great variation in quality regarding the existence of strength and stiffness reducing factors, such as the presence of pith, among others. Resonance vibration has proved to be a suitable and simple way for determining the modulus of elasticity of this timber species. The dynamic flexural modulus of elasticity showed the best correlation with the static MOE, but the correlation between the dynamic longitudinal MOE and the static MOE reached also high values. The efficiency of the method didn't decrease in specimens containing important characteristic imperfections for the species, and consequently may be employed in samples of great variations in quality. The results obtained are consistent with those reported in other investigations for both small clear and structural sizes of different species and provenance.

\section{References}

American Society for testing and materials (1998) ASTM E 187697, Standard test method for Dynamic Young's Modulus, Shear Modulus, and Poisson's Ratio by impulse excitation of vibration. ASTM, West Conshohocken, PA

Glos P (1995) Strength grading. In Timber Engineering STEP 1. Centrum Hout, The Netherlands, pp. A6/1-A6/8

Goens E (1931) Determination of Young's Modulus from flexural vibrations. Ann Phys 11:649-78

Görlacher R (1984) Ein neues Messverfahren zur Bestimmung des Elastizitätsmoduls von Holz. Holz Roh- Werkstoff 42:219-222

Görlacher R (1997) Möglichkeiten der maschinellen Holzsortierung mit dem GradeMaster 403. In Grazer Holzbau-Fachtagung, Sortierung und Festigkeit, B/2:1-10

Hearmon R (1966) Vibration testing of wood. For Prod J 16:29-39

Ilic J (2001) Relationship among the dynamic and static elastic properties of air-dry Eucalyptus delegatensis R. Baker. Holz Roh- Werkstoff 59:169-175

Kollman F, Krech H (1960) Dynamische Messung der elastischen Holzeigenschaften und der Dämpfung. Holz Roh- Werkstoff 18:41-54

Pérez del Castillo A (2001) Propiedades Mecánicas y Calidad de Madera de Eucalyptus Grandis del Norte de Uruguay. Informe de Investigación No 4, LATU, Montevideo

Piter JC, Zerbino RL, Blaß HJ (2004) Visual strength grading of Argentinean Eucalyptus grandis. Strength, stiffness and density profiles and corresponding limits for the main grading parameters. Holz Roh- Werkstoff (in press)

Piter JC, Zerbino RL, Blaß HJ (2004) Machine strength grading of Argentinean Eucalyptus grandis. Main grading parameters and analysis of strength profiles according to European standards. Holz Roh- Werkstoff (in press) 